\title{
The thin green line: sustainable bioenergy feedstocks or invaders in waiting
}

\author{
Larissa L. Smith', Damian J. Allen²,3, Jacob N. Barney' \\ I Department of Plant Pathology, Physiology and Weed Science, Virginia Tech, Blacksburg, VA 24061, USA \\ 2 Department of Agronomy, Purdue University, West Lafayette, IN 47907, USA 3 Mendel BioEnergy Seeds, \\ Mendel Biotechnology Inc., 3935 Point Eden Way, Hayward, CA 94545, USA
}

Corresponding author: Jacob N. Barney (jnbarney@vt.edu)

Academic editor: J. Molofsky | Received 17 September 2014 | Accepted 10 January 2015 | Published 14 April 2015

Citation: Smith LL, Allen DJ, Barney JN (2015) The thin green line: sustainable bioenergy feedstocks or invaders in waiting. NeoBiota 25: 47-71. doi: 10.3897/neobiota.25.8613

\begin{abstract}
Numerous fast growing and highly competitive exotic crops are being selected for production of renewable bioenergy. Tolerance of poor growing conditions with minimal inputs are ideal characteristics for bioenergy feedstocks, but have attracted concern for their potential to become invasive. Miscanthus $\times$ giganteus is one of the most promising bioenergy crops in the US, but grower adoption is hindered by high establishment costs due to sterility. Newly developed fertile tetraploid $M . \times$ giganteus may streamline cultivation while reducing establishment costs. However, fertile seed dramatically increases the potential propagule pressure, and thus probability of off-site plant establishment. To empirically evaluate the invasive potential of fertile $M . \times$ giganteus in the Southeastern US, we compared fitness and spread potential relative to ten grass species comprising 19 accessions under both high and low levels of competition and disturbance. We chose species known to be invasive in the US (positive controls: Arundo donax, naturalized M. sinensis, $M$. sacchariflorus, Phalaris arundinacea, Sorghum halepense) and non-invasive (negative controls; Andropogon gerardii, ornamental M. sinensis, Panicum virgatum, Sorghum bicolor, Saccharum spp.). This novel design allows us to make relative comparisons of risk among species with varying invasiveness. After three years of establishment and growth in Blacksburg, Virginia, neither aboveground disturbance nor interspecific weed competition influenced fitness for fertile $M . \times$ giganteus or our positive and negative control groups. Fertile M. $\times$ giganteus produced $346 \%$ and $283 \%$ greater aboveground biomass than our positive and negative species, respectively. However, fertile $M . \times$ giganteus produced $74 \%$ fewer inflorescences $\mathrm{m}^{-2}$ than our positive controls and $7 \%$ and $51 \%$ fewer spikelets inflorescence ${ }^{-1}$ than the positive and negative control species. After 18 months of growth, we observed the vegetative and seedling spread of three of our positive control species (S. halepense, P. arundinacea, and M. sacchariflorus) outside the cultivated plot
\end{abstract}

Copyright Larissa L. Smith et al. This is an open access article distributed under the terms of the Creative Commons Attribution License (CC BY 4.0), which permits unrestricted use, distribution, and reproduction in any medium, provided the original author and source are credited. 
into receiving areas of both high and low competition. After 24 months of growth, numerous species were observed outside the cultivated plot including fertile $M . \times$ giganteus and $50 \%$ of negative control species. Notably, in three years sterile $M . \times$ giganteus 'Illinois' and Arundo donax never moved from the cultivated plot. The addition of fertile seed appears to increase the potential for offsite movement, but within the geographic confines of our empirical evaluation, fertile $M . \times$ giganteus seedlings are more similar to native $P$. virgatum and were not nearly as fast growing or as competitive as our positive control $S$. halepense. The use of numerous species providing relative comparisons allow us to draw important conclusions which may help prepare for widespread commercialization, while providing novel methodology for ecological risk assessment of new species.

\section{Keywords}

Biofuel, giant miscanthus, habitat susceptibility, invasibility

\section{Introduction}

There is a global push towards renewable biomass based energy (Yauan et al. 2008), and large statured perennial grasses hold the most promise as dedicated energy crops. Candidate feedstocks are ideal because of their perennial growth habit, rapid growth and high annual biomass production, low management and input requirements following establishment, and relatively low pest pressure. However, it is this desirable set of agronomic characteristics which has been the major source of concern for their potential to contribute to the invasiveness of numerous bioenergy crops (Lewandowski et al. 2003; Raghu et al. 2006). Barney and DiTomaso (2010) diagram the "thin green line" between many agronomic weeds, introduced and even subsidized in some cases, for purposes such as forage or erosion control, and the relatively benign crops vitally important to our economy and food supply. However, identifying which side of this line new crops fall is challenging at best.

Spatial demographic models (Matlaga and Davis 2013) and weed risk assessments (Barney and DiTomaso 2008; Davis et al. 2010; Gordon et al. 2011) do offer predictions regarding the ability of novel species to establish and spread. However, in reality, empirical data from in situ field trials, supporting conclusions of invasiveness or longterm sustainability, do not exist. Several candidate bioenergy crops have a history of invasiveness, which is a robust predictor of future invasive potential (Dawson et al. 2009; Gordon et al. 2008). For example, Arundo donax L. is a documented noxious weed of riparian habitats in the southeastern United States (Bell 1997; Katibah 1984). Despite this label, no peer-reviewed data exists evaluating the ability of $A$. donax to spread from a cultivated field. Two miscanthus species in particular have been widely grown in the United States for horticultural use: Miscanthus sinensis Andersson is listed as potentially invasive, but not prohibited in Connecticut (Council 2013), and is known to form extensive infestations after spreading from older or abandoned ornamental plantings (Dougherty et al. 2014; Miller 2003); and M. sacchariflorus (Maxim.) Franch is on the Massachusetts prohibited plant list (Resources 2014), and has repeatedly escaped from cultivation, particularly in the Midwest (Bonin et al. 2014). However, at this time only 
limited studies have begun to examine the invasive potential of bioenergy crops in the context of a managed agricultural cropping system (see Barney et al. 2012; Matlaga et al. 2012b; Quinn et al. 2011).

Crop breeding and improvement will be imperative to improve quality, increase yield, and reduce pest pressure (Gressel 2008). The sterile triploid 'Illinois' variety of Miscanthus $\times$ giganteus J.M. Greef \& Deuter ex Hodkinson \& Renvoize has emerged as one of the most promising bioenergy crops in the US and Europe, but planting is expensive and requires specialized equipment (Lewandowski et al. 2003). Despite the explicit inclusion of $M . \times$ giganteus in the Massachusetts prohibited plant list as a progeny of $M$. sacchariflorus (Resources 2014), qualitative weed risk assessments have suggested that the sterile cultivar is of low risk for invasiveness (Barney and DiTomaso 2008). Newly developed fertile lines of tetraploid $M . \times$ giganteus may streamline cultivation by reducing labor and establishment costs (Sacks et al. 2013); but the addition of fertile seed has the potential to dramatically increase propagule pressure to surrounding habitats, and must be evaluated for its influence on invasiveness.

Despite the vigilant approach with bioenergy crops in regards to invasiveness, the majority of introduced species have neutral ecological consequences and many provide a direct benefit to society (Barney and DiTomaso 2010; Davis 2003). However, the intentional cultivation and transport of exotic bioenergy crops over a vast geographic range would bypass the early environmental filters of introduction and colonization (Barney et al. 2012), as well as the geographical, environmental and reproductive barriers to spread (Richardson and Blanchard 2011; Smith and Barney 2014b). Both vegetative and seed propagules from bioenergy crops will be exposed to a diversity of landscapes along the biofuel supply chain (cultivated field to refinery). Therefore, susceptibility to invasion will need to be evaluated across numerous geographies and habitat types (Smith and Barney 2014b).

Since Herbert Baker $(1965$; 1974) put forth the theory that a set of 12 defining characteristics could identify the 'ideal weed', the importance of traits has been widely debated (Thompson and Davis 2011; van Kleunen et al. 2010). Bioenergy crops have been selected for a suite of agronomic traits making them ideal candidates for cultivation (Lewandowski et al. 2003), but this may also serve as the crux for their potential to become invasive (Raghu et al. 2006). For these reasons, it is imperative that we reflect that no single species is invasive in every location it inhabits. For example, populations of Sorghum halepense L. are particularly devastating in the southeastern United States, earning a reputation as one of the world's worst weeds (Holm et al. 1977). Yet in its northern range, $S$. halepense populations are rarely regarded as detrimental and despite its perennial growth many populations do not overwinter as rhizomes (Warwick et al. 1984), illustrating that both invasiveness and habitat susceptibility vary (Smith and Barney 2014b).

Here we use a comparative framework to relativize the invasive potential of newly developed fertile tetraploid $M . \times$ giganteus. We compare fertile $M . \times$ giganteus against ten grass species, comprising 19 accessions, in four environments. We selected the ten grass species to allow a comparison against species that are known invaders in the 
US (positive controls), and species that are generally considered not to be invasive (negative controls). This design allows us to make important relative comparisons of risk, for candidate bioenergy crops, along a spectrum of invasiveness. We impose both competition and aboveground disturbance treatments to capture a range of conditions which bioenergy crops may encounter in or adjacent to the cultivated field. These treatments allow us to determine conditions that facilitate invasive spread and determine susceptible environments for establishment of nascent populations. This relative methodology was recently tested and proved critical in accurately interpreting the probability of fertile tetraploid $M . \times$ giganteus establishment in a diversity of habitats across the southeastern United States (Smith and Barney 2014b). The objective of this study is to compare the growth and spread potential of fertile $M . \times$ giganteus to known invasive and noninvasive control groupings. Specifically, we aim to: (1) evaluate the invasive potential of fertile $M . \times$ giganteus, during the first three years of establishment and growth, in comparison with 10 species (19 total accessions) of known invasive and non-invasive species in relation to their population dynamics, competitive ability, local recruitment and spread potential; (2) evaluate the performance of each bioenergy crop in response to various levels of competition and disturbance by assessing survival and performance; and (3) quantify seed production as a novel propagule source for $M . \times$ giganteus and compare across our invasiveness diversity panel.

\section{Methods}

\section{Species selection}

In our effort to evaluate the invasive potential of a new fertile tetraploid $M . \times$ giganteus pre-commercial cultivar known as 'PowerCane' ((Sacks et al. 2013); Mendel Biotechnology, Inc., Hayward, CA, USA), which was derived from a population of half-siblings of 'Nagara' (Głowacka et al. 2014), we developed a methodology that includes several species that are known invaders in the southeastern US (hereafter positive controls), as well as species that are generally considered not invasive (hereafter negative controls). In order to make relative comparisons of fertile $M . \times$ giganteus, we selected a range of grasses to represent various growth habits (clumping to spreading) and fertilities that span this invasive spectrum, and that occur regionally (Table 1). Weedy populations of all positive controls are well documented regional invaders (Table 1), and many receive a high risk rating from the Plant Protection and Quarantine Weed Risk Assessment Model (Koop et al. 2011; Smith 2014). Negative controls have been documented as low risk in weed risk assessment models (PIER 2013; Smith 2014), or are native to North America and are not considered highly competitive or weedy in comparison to our positive controls (Simberloff et al. 2012). In some cases multiple accessions (e.g., M. sinensis) or cultivars (e.g., P. virgatum) are included to represent intraspecific variation (Table 1). Despite the weedy reputation of M. sinensis (Dougherty et al. 2014; Miller 2003) we selected accessions intended to represented both positive and negative 
Table I. List of taxa included in the field trials located in Blacksburg, Virginia.

\begin{tabular}{|c|c|c|c|c|c|c|}
\hline Species & Common name & Accession & Source & $\begin{array}{l}\text { Planting } \\
\text { method }\end{array}$ & $\begin{array}{l}\text { Planting } \\
\text { format }^{\S}\end{array}$ & $\begin{array}{c}\text { Invasive } \\
\text { status in } \\
\text { the US }\end{array}$ \\
\hline Andropogon gerardii & big bluestem & Suther & Ernst & seed & $16.5 \mathrm{R}$ & native ${ }^{\prime}$ \\
\hline Arundo donax & giant reed & & Bluemel & plugs & $76 \mathrm{C}$ & invasive \\
\hline Miscanthus sacchariflorus & Amur silvergrass & Robustus & Bluemel & plugs & $76 \mathrm{C}$ & invasive $^{\#}$ \\
\hline M. sinensis & maiden grass & Gracillimus & Bluemel & plugs & $76 \mathrm{C}$ & exotic $^{\dagger \dagger}$ \\
\hline M. sinensis & maiden grass & Dixieland & Bluemel & plugs & $76 \mathrm{C}$ & exotic ${ }^{\dagger \dagger}$ \\
\hline M. sinensis & maiden grass & Cabaret & Bluemel & plugs & $76 \mathrm{C}$ & exotic $^{\dagger \dagger}$ \\
\hline M. sinensis & maiden grass & $\mathrm{OH}$ & UIUC & plugs & $76 \mathrm{C}$ & invasive $^{\text {蛙 }}$ \\
\hline M. sinensis & maiden grass & NC & UIUC & plugs & $76 \mathrm{C}$ & invasive ${ }^{\text {辣 }}$ \\
\hline M. sinensis & maiden grass & KY & UIUC & plugs & $76 \mathrm{C}$ & 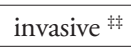 \\
\hline M. sinensis & maiden grass & $\mathrm{PA}$ & UIUC & plugs & $76 \mathrm{C}$ & invasive ${ }^{\text {糔 }}$ \\
\hline M. $\times$ giganteus & giant miscanthus & Illinois & Mendel & plugs & $76 \mathrm{C}$ & exotic $\$ \$$ \\
\hline M. $\times$ giganteus $^{\dagger}$ & PowerCane & M700464 & Mendel & plugs & $76 \mathrm{C}$ & unknown \\
\hline M. $\times$ giganteus & giant miscanthus & Nagara & Mendel & plugs & $76 \mathrm{C}$ & exotic $^{\S \S}$ \\
\hline Panicum virgatum & switchgrass & EG 1101 & Ceres & seed & $16.5 \mathrm{R}$ & native ! \\
\hline P. virgatum & switchgrass & Alamo & Ernst & seed & $16.5 \mathrm{R}$ & native $\mid$ \\
\hline Phalaris arundinacea & reed canarygrass & Palaton & Outsidepride & seed & $16.5 \mathrm{R}$ & invasive " \\
\hline Saccharum spp. & energy cane & US 06-9001 & USDA-ARS & ratoons & $76 \mathrm{C}$ & exotic 99 \\
\hline Saccharum spp. & energy cane & US 06-9002 & USDA-ARS & ratoons & $76 \mathrm{C}$ & exotic"s \\
\hline Sorghum bicolor & biomass sorghum & ES 5201 & Ceres & seed & $76 \mathrm{R}$ & exotic \#\# \\
\hline S. halepense & johnsongrass & & Azlin & seed & $16.5 \mathrm{R}$ & invasive $^{\text {ft† }}$ \\
\hline
\end{tabular}

${ }^{\dagger}$ Following the nothospecies rule from the International Code of Nomenclature for algae, fungi, and plants (IAPT 2012), all progeny and other descendants derived from crossing M. sacchariflorus and $M$. sinensis are by definition $M . \times$ giganteus, irrespective of ploidy and fertility.

¥ Due to issues with availability, Saccharum cultivars were planted in summer 2012, one year later than all other species.

${ }^{\S}$ Planting format in $16.5 \mathrm{~cm}(16.5 \mathrm{R})$ or $76 \mathrm{~cm}(76 \mathrm{R})$ rows, or on $76 \mathrm{~cm}$ centers $(76 \mathrm{C})$.

I(Simberloff et al. 2012); '(Bell 1997); ${ }^{*}$ (Bonin et al. 2014); ${ }^{\dagger \dagger}$ (Madeja et al. 2012); ${ }^{\ddagger}$ (Dougherty et al. 2014); ${ }^{\$ \$}$ (Heaton et al. 2004); "(Kercher et al. 2007); "9 (Gordon et al. 2011); \#\# (Martin et al. 2006); 计 (Holm et al. 1977).

controls. Several M. sinensis ornamental cultivars are poor horticultural performers with low fecundity (Madeja et al. 2012), hence our characterization of low invasive potential in this study.

\section{Experimental design}

A two-factor split-plot design arranged in a randomized complete block, with four replications was established in Blacksburg, Virginia, Schochoh, Kentucky and Auburn, Alabama in 2011. A total of $2013.7 \times 18.3 \mathrm{~m}$ plots were established for each accession with the exception of the four naturalized $M$. sinensis accessions, which were replicated three times at each site due to seed limitation. Within each plot we planted the center 


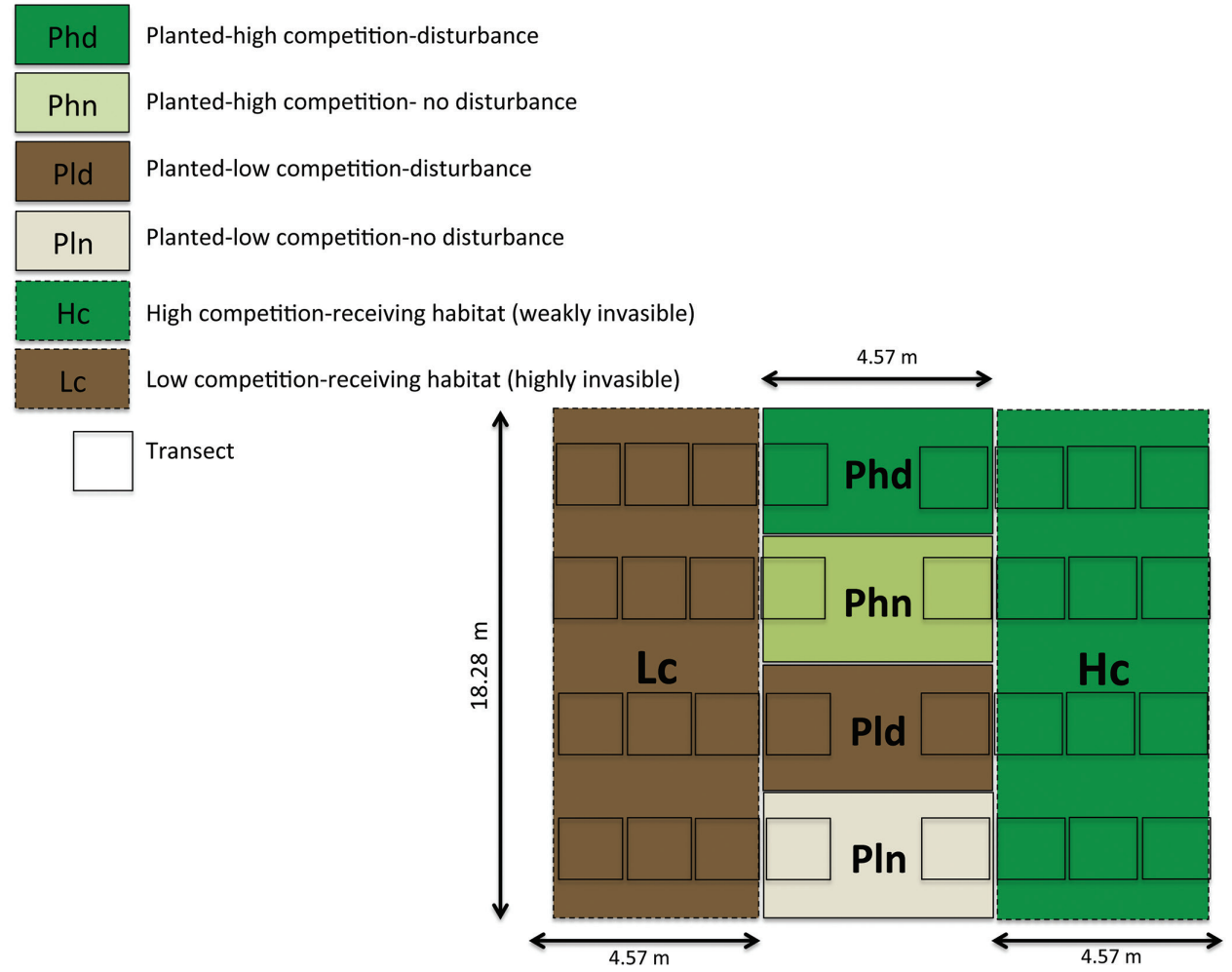

Figure I. A single replicate, showing the two-factor split-plot layout for each of the 76 plots established in Blacksburg, VA.

$4.6 \times 18.3 \mathrm{~m}$ with the target taxon, which is flanked by an equally-sized receiving area on either side. The planted plot was divided into four $4.6 \times 4.6 \mathrm{~m}$ subplots $\left(20.88 \mathrm{~m}^{2}\right)$ randomly assigned to one of the following treatments (Figure 1): high competition/ no disturbance (Phn); high competition/ disturbance (Phd); low competition/ no disturbance (Pln); low competition/ disturbance (Pld). The disturbance treatment refers to annual aboveground biomass removal in the fall of each year (beginning December 2011), while a no disturbance treatment is defined by the absence of annual harvest, in which all plant material was left standing in the field for the duration of this study. The high competition treatment refers to no weed management action taken following initial establishment (after July 2011). High competition plots included dense populations of both winter (i.e., Lamium sp. and Stellaria sp.) and summer annual weeds (i.e., Ipomoea sp., Amaranthus sp., Setaria sp., and Conyza canadensis (L.) Cronquist). Low competition is defined as intensive weed management to maintain a near weed-free ( - bare ground) environment throughout the duration of the experiment. Each flanking unplanted $4.6 \times 18.3 \mathrm{~m}$ "receiving habitat" was also randomly assigned to either intensive management for weeds (Lc) or no management (Hc) (Figure 1), to assess the local spread of each species as a function of habitat type. The Hc receiving areas 
were composed of the same winter and summer annual weeds as above. Weedy plots represent a relatively high competition habitat, while the weed-free plots represent a relatively low competition habitat. Each plot was surrounded with a $1.5 \mathrm{~m}$ buffer of mowed Schedonorus arundinaceus (Schreb.) Dumort (tall fescue).

\section{Site}

This experiment was established at the Kentland Research Farm near Blacksburg, VA USA $\left(37^{\circ} 12^{\prime} \mathrm{N}, 80^{\circ} 35^{\prime} \mathrm{W}\right)$, on 10 June 2011, Walnut Grove Farms, Schochoh, KY $\left(36^{\circ} 45^{\prime} \mathrm{N}, 86^{\circ} 45^{\prime} \mathrm{W}\right)$ on 15 June 2011, and Auburn, Alabama on 30 May 2011 $\left(32^{\circ} 26^{\prime} \mathrm{N}, 85^{\circ} 52^{\prime} \mathrm{W}\right)$. However, due to unforeseen circumstances beyond our control, the Kentucky and Alabama locations were eradicated within the first year of the study. Therefore, neither will be discussed further. We understand the limitations of a single geographic location in years two and three of this study; but due to the proprietary nature of the 'PowerCane' and 'Nagara' plant material, we were limited by site availability. It should be noted that other important ecological studies have been carried out using a single location (Von Holle 2005; Von Holle and Simberloff 2005). However, our results should be viewed within the limited geographic representation. Soil samples were collected in early June 2011, using a $20 \mathrm{~cm}^{3}$ soil corer, and submitted for analysis at the Virginia Cooperative Extension Soil Testing Laboratory at Virginia Tech. The Blacksburg field site was planted on a Ross loam occluding a Wheeling silt loam (USDA-NRCS 2013) with a $\mathrm{pH}$ of 6.4, and a recent cropping history of continuous corn with a winter rye cover crop. In May 2011 the field was treated with $1 \mathrm{~kg}$ acid equivalent $\mathrm{ha}^{-1}$ glyphosate. The rye cover crop was mowed and bailed in preparation for planting.

\section{Establishment}

Vegetatively propagated accessions (Table 1) were started in the greenhouse from rhizome/root crown fragments and delivered to the field sites just prior to planting. Seed from naturalized accessions of $M$. sinensis were collected the previous year from established populations in Kentucky, Pennsylvania, North Carolina and Ohio. Seeds were planted individually into 127 cell flats in March 2011 and greenhouse grown. The field was not tilled prior to planting in accordance with a no-till cropping system. Miscanthus plugs were planted on $76 \mathrm{~cm}$ centers using a no-till plug planter (RJ Equipment, Ontario, Canada). Larger plant material such as $A$. donax required hand planting, because pieces were too large for the transplanting equipment. All remaining seeded feedstocks were drilled on 16.5 or $76 \mathrm{~cm}$ rows using a no-till drill (Table 1). Seeding rate was adjusted based on commercially determined pure live seed or (laboratory) germination rates, to deliver $-22,000$ plants $\mathrm{ha}^{-1}$, which was comparable to our transplant density. As our study aims to evaluate establishment, persistence and spread, 
annual Sorghum bicolor L. was not replanted annually after June 2011. Saccharum US 06-9001 and US 06-9002 were not planted until May 2012, due to delays in germplasm availability.

To improve stand establishment, the entire field site received $350 \mathrm{~g}$ ai ha ${ }^{-1}$ and 822 $\mathrm{g}$ ai ha ${ }^{-1} 2,4-\mathrm{D}$ on July 6 and July 25 respectively. Following the July herbicide application we decided that sufficient time for seedling/plug establishment had elapsed, and thus no further herbicide applications were made in the high competition plots (Phn and Phd). No herbicide treatments were imposed in the high competition receiving habitat $(\mathrm{Hc})$. Herbicide treatments of $1060 \mathrm{~g}$ ai ha ${ }^{-1} 2,4-\mathrm{D}$ plus $560 \mathrm{~g}$ ai ha ${ }^{-1}$ dicamba were sprayed on August 20, 2011, in the low competition plots (Pld and Pln) and low competition receiving habitats (Lc). Supplemental hand weeding was done as needed. A second treatment of 2,4-D and dicamba (1060 $\mathrm{g}$ ai ha- ${ }^{-1}$ and $560 \mathrm{~g}$ ai harespectively) was applied on September 25. Low competition plots received $1680 \mathrm{~g}$ ai $\mathrm{ha}^{-1}$ atrazine at the beginning of the second and third growing seasons. Herbicide treatments of $1060 \mathrm{~g}_{\text {ai h }}{ }^{-1} 2,4-\mathrm{D}$ plus $560 \mathrm{~g}^{2}$ ha $^{-1}$ dicamba and $31.5 \mathrm{~g}$ ai ha ${ }^{-1}$ halosulfuron including a $1 \% \mathrm{v} / \mathrm{v}$ nonionic surfactant were applied approximately once a month to maintain weed free status within plots and in the low competition receiving habitat. A $1 \mathrm{~kg}$ ae ha ${ }^{-1}$ application of glyphosate was also used to selectively spot treat non-target grass weeds when hand weeding was not time effective.

\section{Measurements}

Spring data collection occurred in May of 2012 and was repeated in May 2013, while fall data collection occurred in November of each year prior to harvest. To characterize population demography, seedling recruitment and individual plant performance, we placed two $0.9 \times 1.2 \mathrm{~m}$ quadrats in the middle of each sub-plot adjacent to the receiving habitat (Figure 1). Previous germination studies of $M . \times$ giganteus 'Illinois' failed to yield evidence of fertile seed (Matlaga et al. 2012b); thus, any Miscanthus seedlings observed within our plots of $M . \times$ giganteus 'Illinois' and 'Nagara', both of which are sterile, were broadly designated Miscanthus spp. and assumed to have moved beyond the $4.6 \times 18.3 \mathrm{~m}$ receiving area of Miscanthus spp. Due to the large number of visually identical Miscanthus spp. seedlings and lack of available tools for determining genetic lineage, we made the assumption that any Miscanthus seedling found within a seed bearing Miscanthus (M. sinensis or 'PowerCane') plot or receiving area was the progeny of plants associated with that specific plot. The same assumption was also made for the two cultivars of $P$. virgatum. Measurements include plant density, canopy height to the tallest node, culm number per plant, number of inflorescences per plant and basal plant diameter. After two growing seasons the habit of $S$. halepense, M. sacchariflorus and $P$. arundinacea made it impossible to distinguish vegetative ramets from adjacent plants or seedlings, hence our need to base all measurements on culms per unit area rather than the number of individuals. In the receiving habitats, data was collected in 
three $0.9 \times 1.2-\mathrm{m}$ quadrats arranged as a transect perpendicular to the planted plot, adjacent to the planted area until the end of the $4.57 \mathrm{~m}$ receiving habitat (Figure 1 ). The same metrics as above were collected for newly emerged plants found in the receiving habitat (of any of the 20 accessions in this study). Five inflorescences were randomly harvested from each subplot in November 2013. Total spikelet number for each inflorescence was recorded with the exception of the sterile $A$. donax, $M . \times$ giganteus 'Illinois', and M. × giganteus 'Nagara' (Mariani et al. 2010; Matlaga et al. 2012a). Three replications of 100 seeds for each "fertile" accession were surface sterilized with $10 \%$ bleach for 30 seconds and rinsed with deionized water. Seeds were then placed on germination paper in $9.5 \times 9.5 \mathrm{~cm}$ sealed petri plates with $\sim 10 \mathrm{ml}$ deionized water and germination was monitored for four weeks. Harvest treatments were imposed from November to January in each year as weather permitted.

\section{Follow up}

Upon termination of the experiment, the entire field was sprayed with $2 \mathrm{~kg}$ ae ha-1 glyphosate in late 2013 and early 2014. All plant material was harvested, removed from the site and burned as was done with the harvested material in 2012 and 2013. In late summer 2014 we applied $7 \mathrm{~L} \mathrm{ha}^{-1}$ imazapyr. Glyphosate-tolerant corn or soybeans will be planted in the spring of 2015, and a three-year scouting and weed management plan will be implemented to ensure all propagules have been removed from the site. It should be noted that no individuals of any species have been detected outside the experimental area to date.

\section{Statistical analysis}

Analysis of variance (ANOVA) was performed on fitness parameters using JMP 10 statistical software (SAS Institute, Cary, North Carolina, USA). Aboveground biomass, height, culm number, inflorescence number, seed number, and seedling density were analyzed as a mixed model. Treatments and accessions are considered fixed effects, with the 20 accessions nested within designated invasiveness groups (positive and negative controls), while blocks were considered a random effect. Numerous transformations were performed, depending on measurement and year, to achieve normality of residuals. All interactions varied by year, and we were only interested in within year comparisons. Therefore, we did not perform a repeated measures analysis, and look at the variance structure within each of the three years. When significant treatment effects occurred, means were compared with Tukey-Kramer test at alpha $<0.05$, or when more complex interactions were significant, means were compared with a priori orthogonal contrasts at alpha $<0.05$. The 20 individual accessions in our study had an underlying structure (invasiveness groupings), central to our 
experimental design. To objectively determine if our measured traits were capable of partitioning the accessions into the invasiveness groups we performed a canonical discriminant analysis. Kenkel et al. (2002) suggest canonical discriminant analysis is appropriate to examine the relationships between our transformed fitness metrics height, culm and inflorescence number, and spikelet production (covariates) and our invasiveness response variables.

\section{Results}

\section{Establishment (year 1)}

Growth in the first year of all 19 perennial grasses was low as expected. Establishment was well below our target density of 22,000 plants ha- ${ }^{-1}$ for the negative controls $A$. gerardii and ornamental cultivars of $M$. sinensis. Despite heavy and uniform weed pressure in weedy plots, competition had no influence on aboveground biomass, culms $\mathrm{m}^{-2}$, height or inflorescences $\mathrm{m}^{-2}$ (Table 2). Miscanthus $\times$ giganteus 'PowerCane' ('Powercane' hereafter) and our positive control group were taller $(P<0.001)$ and produced more culms $\mathrm{m}^{-2}(P<0.001)$ than the negative control group (Figure 2$)$. The negative control group did produce $46 \%$ and $84 \%$ greater aboveground biomass than 'PowerCane' and the positive control group respectively. Alternatively, our positive control group produced eight-fold more inflorescence $\mathrm{m}^{-2}$ than 'PowerCane' and our negative controls, which did not differ from one another. Sorghum bicolor (negative control), the only annual species in our trial, was taller $(244 \pm 15 \mathrm{~cm})$ and had significantly greater aboveground biomass $\left(15 \pm 6 \mathrm{Mg} \mathrm{ha}^{-1}\right)$ than all other taxa $(P=0.0014)$. Sorghum halepense (positive control) produced the greatest number of inflorescences $\left(74.9 \pm 6.4 \mathrm{~m}^{-2}\right)$ in the first year, while 'PowerCane' produced only 1.3 \pm 0.2 inflorescences $\mathrm{m}^{-2}$. None of the 20 accessions evaluated here spread outside the cultivated plot into either adjacent receiving area after one growing season.

\section{Year 2}

By 12 months after planting, two culms of $M$. sacchariflorus were observed to have spread into the high competition (Hc) receiving area; no culms were found in the low competition (Lc) receiving area. Sorghum halepense spread extensively 0 and $1.5 \mathrm{~m}$ into both the Lc $\left(198 \pm 18\right.$ culms $\left.\mathrm{m}^{-2}\right)$ and Hc $\left(152 \pm 33\right.$ culms $\left.\mathrm{m}^{-2}\right)$ receiving areas.

In fall 2012, M. × giganteus 'PowerCane' was taller $(267.5 \pm 11.6 \mathrm{~cm})$ and produced more culms $\left(130 \pm 22 \mathrm{~m}^{-2}\right)$ than negative controls and had greater aboveground biomass $\left(26 \pm 3 \mathrm{Mg} \mathrm{ha}^{-1}\right.$ ) than the positive and negative control groups (Figure 2). Competition treatments influenced biomass, culm number, and height, while disturbance had no effect on any measured parameter (Table 2). However, competition from unmanaged weeds did not reduce 'PowerCane' height $(P=0.1571)$, culm number 
Table 2. Results of a mixed model ANOVA to evaluate competition and disturbance on aboveground biomass, culm number, number of inflorescences, and height for 20 accessions nested within invasiveness groups observed over three growing seasons in Blacksburg, VA.

\begin{tabular}{|c|c|c|c|c|c|c|c|}
\hline & & df & Biomass & df & Culm number & Height & Inflorescence number \\
\hline \multirow[t]{5}{*}{ Year 1} & Block & 3 & 0.2267 & 3 & 0.1104 & 0.3410 & \begin{tabular}{|c|}
0.0093 \\
\end{tabular} \\
\hline & Species invasiveness & 2 & $<.0001$ & 2 & $<.0001$ & $<.0001$ & $<.0001$ \\
\hline & Species (species invasiveness) & 15 & $<.0001$ & 19 & $<.0001$ & $<.0001$ & $<.0001$ \\
\hline & Competition & 1 & 0.7651 & 1 & 0.1297 & 0.9889 & 0.5704 \\
\hline & Competition $\times$ species invasiveness & 2 & 0.2267 & 2 & 0.1482 & 0.8867 & 0.9010 \\
\hline \multirow[t]{9}{*}{ Year 2} & Block & 3 & 0.3444 & 3 & 0.1365 & 0.4277 & 0.2615 \\
\hline & Species invasiveness & 2 & $<.0001$ & 2 & $<.0001$ & $<.0001$ & $<.0001$ \\
\hline & Species (species invasiveness) & 17 & $<.0001$ & 17 & $<.0001$ & $<.0001$ & $<.0001$ \\
\hline & Competition & 1 & 0.0475 & 1 & 0.0087 & 0.8145 & 0.0003 \\
\hline & Disturbance & --- & --- & 1 & 0.8393 & 0.5382 & 0.9390 \\
\hline & Competition $\times$ species invasiveness & 2 & 0.0205 & 1 & 0.9876 & 0.0411 & 0.8763 \\
\hline & Disturbance $\times$ species invasiveness & --- & --- & 2 & 0.9258 & 0.3361 & 0.1236 \\
\hline & Competition $\times$ disturbance & --- & $-\ldots$ & 1 & 0.5873 & 0.8950 & 0.9295 \\
\hline & $\begin{array}{l}\text { Competition } \times \text { disturbance } \times \text { species } \\
\text { invasiveness }\end{array}$ & --- & ---- & 2 & 0.9879 & 0.5629 & 0.2624 \\
\hline \multirow[t]{9}{*}{ Year 3} & Block & 3 & 0.6655 & 3 & 0.3943 & 0.0021 & 0.5631 \\
\hline & Species invasiveness & 2 & $<.0001$ & 2 & $<.0001$ & $<.0001$ & 0.0818 \\
\hline & Species (species invasiveness) & 16 & $<.0001$ & 17 & $<.0001$ & $<.0001$ & $<.0001$ \\
\hline & Competition & 1 & 0.2491 & 1 & 0.2686 & 0.3401 & 0.5298 \\
\hline & Disturbance & 1 & 0.1074 & 1 & 0.8797 & 0.2327 & 0.1519 \\
\hline & Competition $\times$ species invasiveness & 2 & 0.1041 & 1 & 0.4864 & 0.5878 & 0.5585 \\
\hline & Disturbance $\times$ species invasiveness & 2 & 0.0742 & 2 & 0.6574 & 0.7645 & 0.6781 \\
\hline & Competition $\times$ disturbance & 1 & 0.3392 & 1 & 0.5440 & 0.4407 & 0.8374 \\
\hline & $\begin{array}{l}\text { Competition } \times \text { disturbance } \times \text { species } \\
\text { invasiveness }\end{array}$ & 2 & 0.8225 & 2 & 0.6979 & 0.4895 & 0.8232 \\
\hline
\end{tabular}

( $P=0.3867$ ) or biomass ( $P=0.2928$ ). Competition reduced biomass $56 \%$ and $70 \%$ and culm numbers $26 \%$ and $53 \%$ of positive and negative control groups, respectively. Interestingly, inflorescence production was not influenced by competition, with positive controls and 'PowerCane', both producing a mean of 62 inflorescences $\mathrm{m}^{-2}, 95 \%$ more than negative controls (Figure 2). Sorghum halepense again produced the greatest number of inflorescences $\left(186 \pm 15 \mathrm{~m}^{-2}\right)$ among the positive control group, $118 \%$ more than naturalized $M$. sinensis $\mathrm{PA}$, which ranked second for inflorescence production.

No further spread of $M$. sacchariflorus was observed between the spring and fall 2012. Phalaris arundinacea was observed in the Lc receiving area with $2.7 \pm 2.1$ culms $\mathrm{m}^{-2}$ at a distance of 0 to 1.5 meters from the planted plot. Population density of $S$. halepense continued to increase from year one to year two in the Lc and Hc receiving areas. At the 3 to $4.5 \mathrm{~m}$ distance, culm number increased by 584\% (from 19 to $130 \pm$ $17 \mathrm{culm} \mathrm{m}^{-2}$ ) in the Lc receiving area and $420 \%$ (from 5 to $26 \pm 7 \mathrm{culms} \mathrm{m}^{-2}$ ) in the Hc receiving area. 

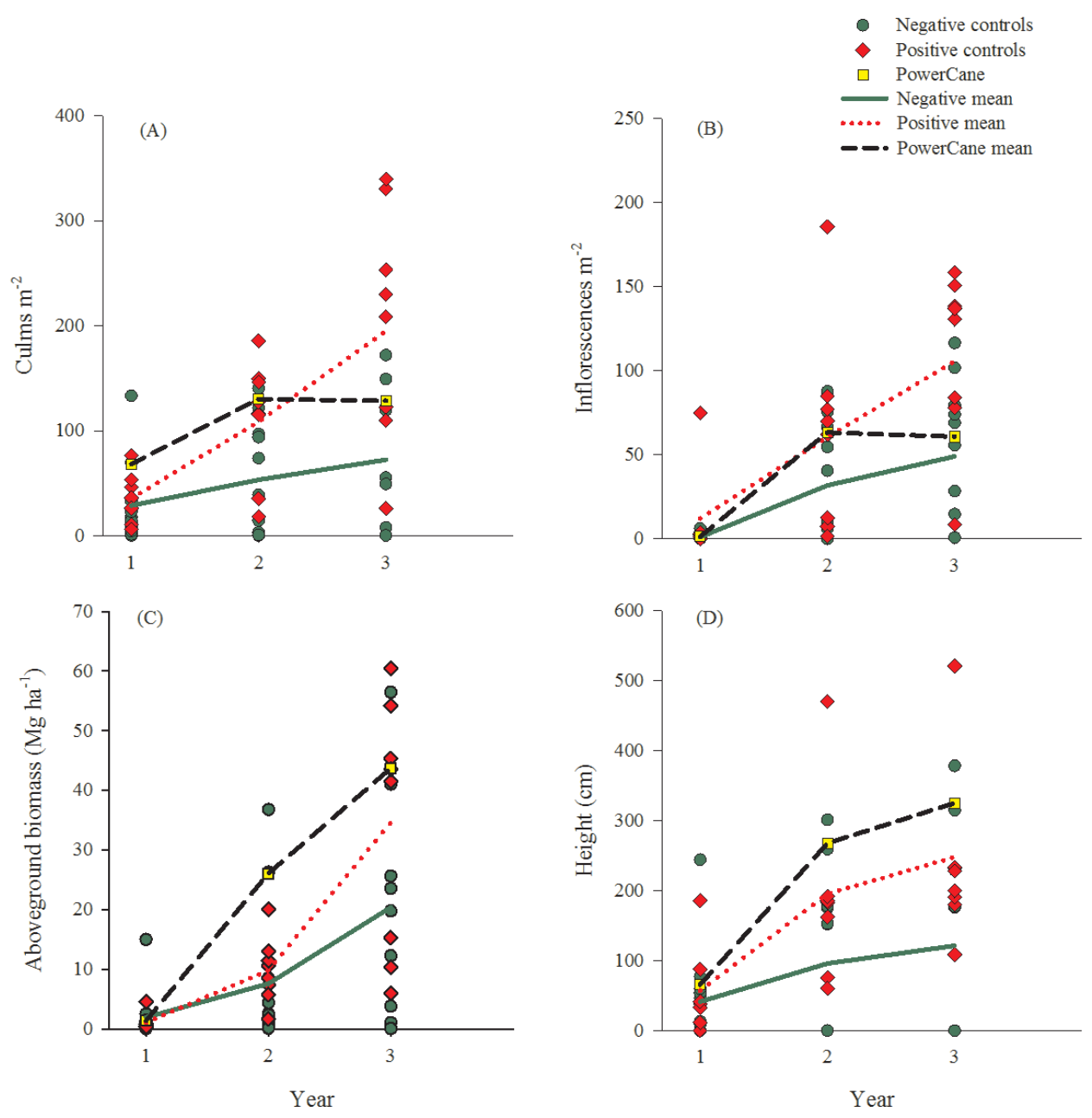

Figure 2. Mean culms (A), inflorescences (B), aboveground biomass $(\mathbf{C})$, and height $(\mathbf{D})$ for 10 species (20 total accessions) observed over three growing seasons in Blacksburg, VA.

\section{Year 3}

Local spread of positive control species $S$. halepense, P. arundinacea, and $M$. sacchariflorus increased in year three in both Lc and Hc receiving areas. For the first time we observed seedlings of $P$. virgatum, $A$. gerardii and ornamental cultivars of $M$. sinensis (negative controls), 'PowerCane', and naturalized accessions of M. sinensis (positive controls) outside the cultivated plot in both Lc and Hc receiving areas.

We saw no influence of either competition or disturbance on biomass, culm number, height, or inflorescence number in the third growing season (Table 2). 'PowerCane' was taller $(325 \pm 12 \mathrm{~cm})$ and produced greater aboveground biomass (43.7 \pm $6.8 \mathrm{Mg} \mathrm{ha}^{-1}$ ) than both positive and negative control groups (Figure 2). However, our 

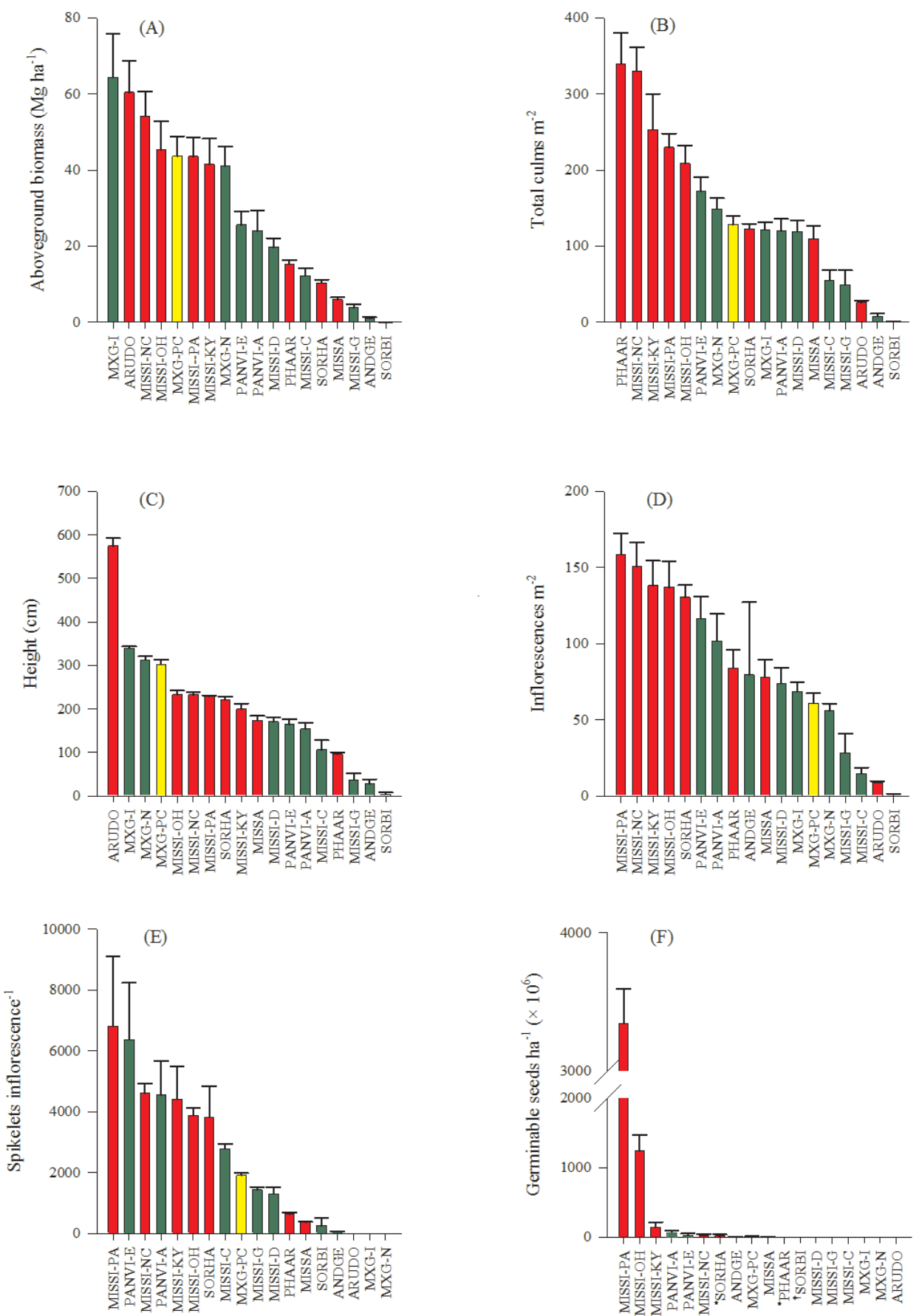

Figure 3. The ranked aboveground biomass $(\mathbf{A})$, culms $(\mathbf{B})$, height $(\mathbf{C})$, inflorescences $(\mathbf{D})$, spikelets $(\mathbf{E})$, and germinable seeds (F) for 18 accessions (two year-old Saccharum, spp. were omitted), recorded at the end of the third growing season. Accessions marked with * indicate that seeds appeared immature at time of germination testing, and $\dagger$ indicate that seeds had extreme fungal and insect damage at the time of harvest. 


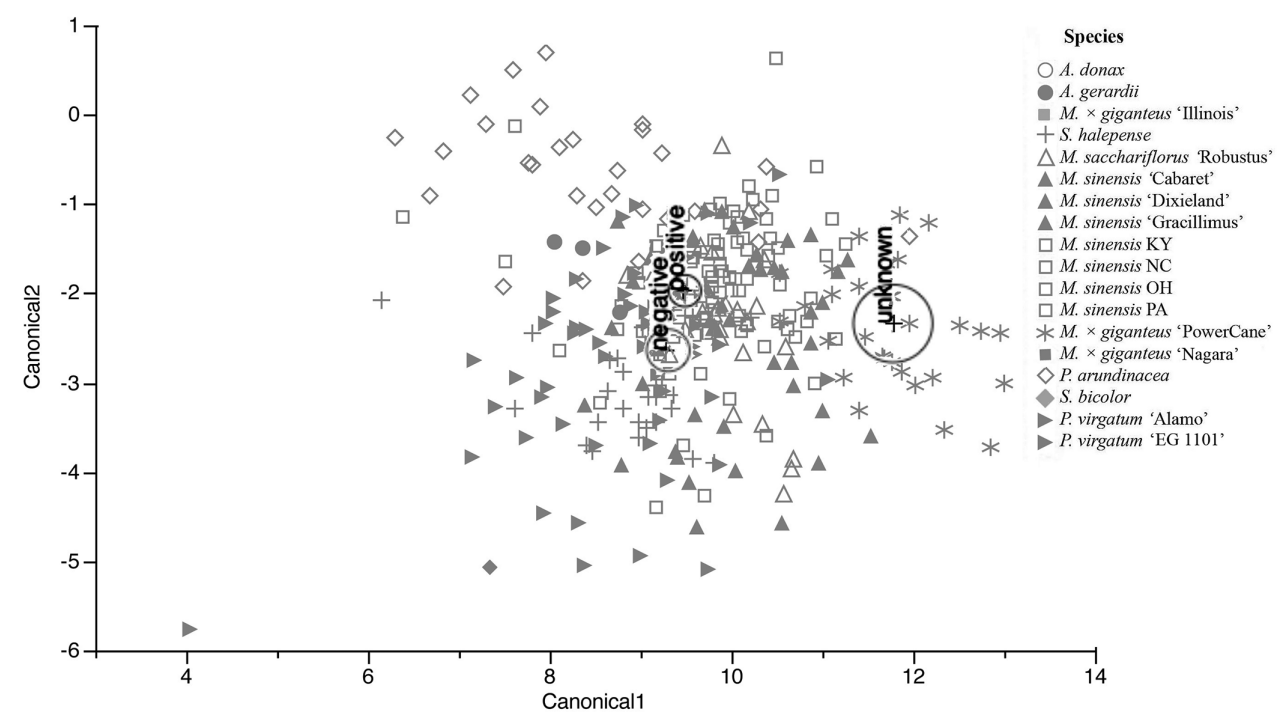

Figure 4. Canonical discriminant analysis plot for the species invasiveness groupings positive controls, negative controls and $M . \times$ giganteus 'PowerCane'. The fitness parameters biomass, culm and inflorescence number, height and spikelet production were used as predictors.

positive controls produced $52 \%$ more culms $\mathrm{m}^{-2}$ and $74 \%$ more inflorescences $\mathrm{m}^{-2}$ than 'PowerCane' (Figure 2). 'PowerCane' produced 2,163 \pm 80 spikelets inflorescence $^{-1}$, significantly fewer than our positive control group $(3,226 \pm 534$ spikelets inflorescence ${ }^{-1}$ ) (Figure 3). 'PowerCane' seeds also exhibited low germinability with only one of 300 spikelets germinating after four weeks. Alternatively, two naturalized accessions of $M$. sinensis, $\mathrm{PA}$ and $\mathrm{OH}$, had the highest seed germination rates $(31 \%$ and $16 \%$ respectively) (Figure 3 ). The rank of performance varied among accessions and invasive groups among the functional traits recorded (Figure 3). When our functional traits were used as predictors, canonical discriminant analysis failed to show clustering of our invasive groups, with a predictive value $<62 \%$ (Figure 4 ).

In all cases, seedling or vegetative spread into adjacent receiving areas was greater in the Lc receiving area compared with the Hc receiving area (Figure 5). A significant interaction between invasive groups and receiving area competition was observed at the 0 to $1.5 \mathrm{~m}(P<0.001)$ and 1.5 to $3 \mathrm{~m}(P=0.04041)$ distances from the cultivated plot (Figure 5). While the greatest number of culms $\mathrm{m}^{-2}$ were observed in the 'PowerCane' Lc receiving areas, numbers were not different from those found in the positive control Lc plots. In the Hc receiving areas, culms $\mathrm{m}^{-2}$ produced by 'PowerCane' was equivalent to that of the negative control group. It should also be noted that, at no time were any of the sterile clones in this study $(A$. donax or $M . \times$ giganteus 'Illinois' and 'Nagara') observed to spread vegetatively outside of their associated planted plot. 

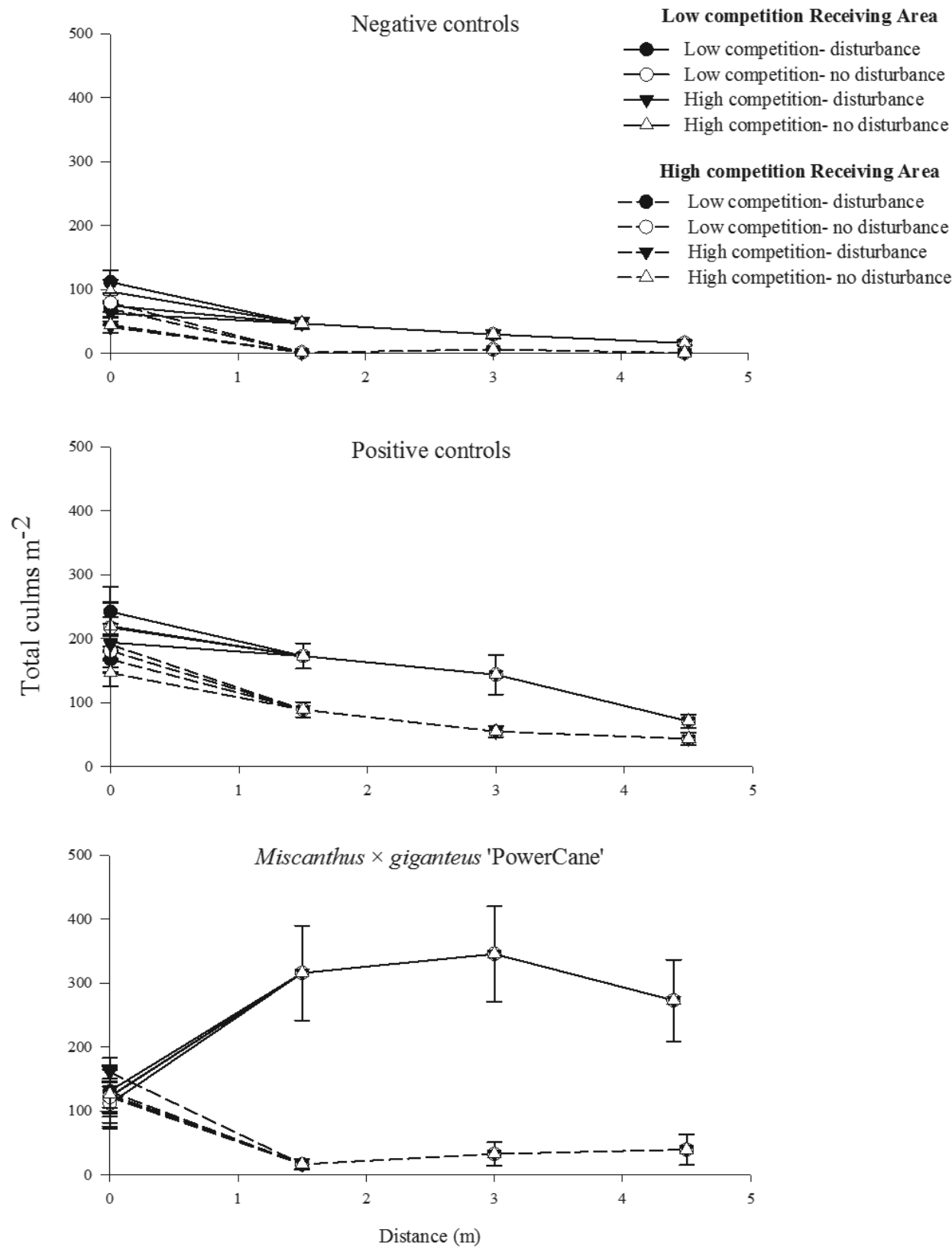

Figure 5. Total number of vegetative and seedling culms $\mathrm{m}^{-2}$ observed within the cultivated plot (distance $0 \mathrm{~m}$ ), and in the Lc, low competition (intensive weed management) and Hc, high competition (no weed management) receiving areas from a distance of 0.1 to $4.5 \mathrm{~m}$ from the cultivated plot, after three growing seasons. 


\section{Discussion}

All taxa in our study established under all treatment conditions, and all fertile crops produced offspring, with the exception of the two Saccharum spp., which were only grown for two years. Despite enhanced traits for cold tolerance, these cultivars may have been well beyond their suitable geographic range in Blacksburg, VA (Barney and DiTomaso 2011) because they were the only species in this study to decrease in biomass $\left(1300 \% \mathrm{Mg} \mathrm{ha}^{-1}\right)$ and culm number $(380 \%)$, as well as fail to produce inflorescences; however, the lack of inflorescences production was not unexpected as several abiotic factors are responsible for inhibiting and inducing tasseling, such as temperature and photoperiodism (LaBorde 2007).

Though all of the perennial species in our study have the ability to spread vegetatively, local spread was equivocal. Despite the three year clonal expansion of sterile $M$. $\times$ giganteus 'Illinois' $\left(0.23 \mathrm{~m}^{2}\right.$ plant $^{-1}$ increase in area $)$ and $A$. donax $\left(0.28 \mathrm{~m}^{2} \mathrm{plant}^{-1}\right.$ increase in area), this did not contribute to nascent plants outside the cultivated plot. Unlike the culms of most species in our study, which die back at the end of each growing season, the culms of $A$. donax remain dormant during the winter months (Saltonstall et al. 2010). Arundo donax produced $33 \pm 1$ nodes $\mathrm{culm}^{-1}$; the majority of which produced new axial shoots each growing season. Despite overwhelming evidence of $A$. donax clonal spread in warm riparian or coastal freshwaters of the southwestern United States (Bell 1997; Quinn and Holt 2008; Seawright et al. 2009); the numerous culms we observed, bending to the ground at the perimeter of our plots, failed to root and produce new ramets; so called layering (Boland 2006). It has been suggested that the probability of a plant becoming invasive increases with the ability to reproduce vegetatively (Kolar and Lodge 2001). The only species in our trial for which vegetative reproduction appeared to contribute to invasive spread were $S$. halepense, $M$. sacchariflorus, and $P$. arundinacea (all positive controls), all of which began to spread from the planted plots in the second growing season. Conversely, Pyšek and Richardson (2007) argue that while vegetative traits may benefit persistence, the ability to spread may be hindered by vegetative reproduction, especially if seed production is limited or absent. In agreement with our results, all of the caespitose grasses in our study failed to spread vegetatively beyond the borders of the planted plot under our growing conditions.

The production of fertile seed enhanced the ability of many species to spread, but only locally. Sorghum halepense was the only accession to have large numbers of first season inflorescences (Figure 2B), and so it is not surprising that this was the only species to generate seedling volunteers in the second year. In contrast, most taxa increased inflorescence production in the second season, extending the range of species detected as seedlings in the receiving areas in the third season. With the exception of 'PowerCane', inflorescence numbers continued to increase from the second to the third growing season, suggesting that propagule pressure in the receiving plots did not reach a plateau during the experiment. While other factors such as habitat invasibility and timing are essential to invasive success (Barney and Whitlow 2008), this dramatic increase in propagule pressure facilitated establishment of 'PowerCane' seedlings in 
both the Lc and Hc receiving area, though recruitment varied dramatically between the habitats. Inflorescence production and therefore the total number of spikelets plot $^{-}$ ${ }^{1}$ in our three invasive groups increased between year one and year three. Even small increases in propagule pressure can result in a substantial increase in invasion pressure even in inhospitable environments (Davis 2009), which likely contributed to the observed lag.

The more individuals released into an environment the higher the probability that some propagules will endure environmental barriers and overcome stochastic biotic and abiotic factors (Blackburn et al. 2009). The number of introduced individuals, therefore, has a substantial influence on establishment success (Lockwood et al. 2009). Seeds of $A$. gerardii, $P$. virgatum and $P$. arundinacea are known to have variable dormancy and potentially low seedling vigor (Beckman et al. 1993; Lewandowski et al. 2003; Parrish and Fike 2005; Smart et al. 2003), which agreed with our observations in the establishment year. Miscanthus sacchariflorus (positive control) has been reported to have low seed set, -746 viable seeds mature plant ${ }^{-1}$, with population growth predominantly due to vegetative spread (Madeja et al. 2012). Despite these assumptions, $1 \%$ of tested $M$. sacchariflorus seeds did germinate, which was greater than seed germinability of 'PowerCane' $(0.3 \%)$ and $M$. sinensis NC (0.6\%). Previous research has shown ornamental cultivars of $M$. sinensis are extremely variable, ranging from 190,000 seeds plant ${ }^{-1}$ to 3,100 in 'Gracillimus', 785 in 'Dixieland' and 0 filled spikelets plant $^{-1}$ in 'Cabaret' (negative controls) (Madeja et al. 2012; Meyer and Tchida 1999). Results from our seed germination testing support these conclusions in which no ornamental $M$. sinensis seeds germinated; however, we observed high variability (31\% to $0.6 \%$ ) in germinability for naturalized $M$. sinensis accessions (Figure 3). Dougherty et al. (2014) showed that $-44 \%$ of seed from weedy accessions of $M$. sinensis germinated in a laboratory setting. Previous research indicates that both inflorescence and spikelet production in almost all $M$. sinensis cultivars are positively correlated with plant hardiness zone (Madeja et al. 2012; Meyer and Tchida 1999; Wilson and Knox 2006); indicating that invasion pressure for these species may vary with latitude.

After three years of growth, all naturalized accessions of $M$. sinensis produced a greater number of inflorescences $\mathrm{m}^{-2}$ and more spikelets inflorescence ${ }^{-1}$ than 'PowerCane' (Figure 3). In this study, 'PowerCane' produced $\sim 1.3$ billion spikelets ha $^{-1}$ in the third growing season, which would yield 3.9 million viable seed ha ${ }^{-1}$ given the $0.3 \%$ germination rate. It is possible that we saw greater numbers of seed produced than in a production field; like P. virgatum (Martinez-Reyna and Vogel 2002), Miscanthus spp. are self-incompatible (Hirayoshi et al. 1955). The genetic diversity among the accessions and species in our study, ideal for outcrossing species, may have led to inflated seed production (Madeja et al. 2012) compared to the relative genetic homogeneity common in commercial crops. In this case genetic variability not only increases the likelihood of seed production, but also has the potential to enhance establishment success and increase the habitat range of exotic species (Lockwood et al. 2005).

Surprisingly, none of the accessions were affected by the level of competition, which not only contradicts much of the literature suggesting the need for weed man- 
agement at establishment (Lewandowski et al. 2003), but supports the conclusion that these species are fast growing and highly competitive (Raghu et al. 2006). The high seedling establishment of 'PowerCane' in the Lc and lower seedling establishment numbers in the $\mathrm{Hc}$, appears to contradict our recent findings in which only $0.1 \%$ of emerged 'PowerCane' seedlings survived after six months (Smith and Barney 2014b). However, our earlier study indicated the majority of 'PowerCane' seedlings emerged in areas of available bare ground and low resident plant competition such as agricultural fields and forest understories. However, annual weed species dominated our Hc receiving area, which created open spaces and the availability of bare ground during the winter months and early spring, coinciding with annual seed dispersal for many of these late flowering species. The small, light seed and ciliate lemma (Gleason 1952) of Miscanthus spp. is valuable for dispersal. However, the ciliate lemmas appear to interfere with the ability of Miscanthus seed to make important soil contact required for germination, which is evident in areas of high resident plant competition and litter (Smith and Barney 2014b). According to Quinn et al. (2011), the anemochorous $M$. sinensis spikelets have been shown to disperse an average of $50 \mathrm{~m}$. Therefore, open areas of low resident plant competition near production sites will likely be the most susceptible, suggesting that our Lc plots represent a worst case scenario. This information will be critical for identifying susceptible habitats near cultivated fields and will be important considerations for management.

Despite the utility of trait-based research for helping to make associations and guide management, traits do not confer absolute predictability. Invasions will always be contingent on a number of interacting factors (Barney et al. 2008; Dredovsky et al. 2012). Hence, our experimental design was critical in the interpretation of our results. Clearly this geographic location, habitat and treatment factors were ideal for a species such as $S$. halepense; a species intentionally introduced for agronomic purposes, which now flourishes in agricultural and anthropogenic systems of the southeastern U.S. (Warwick and Black 1983). However, despite the reputation of $A$. donax as an aggressive riparian invader, this species appeared to be constrained by the non-riparian landscape.

The selection of our invasive and noninvasive taxa was a novel methodology used to make important relative comparisons. The ten species selected in this study are of similar life form, and all of them, including S. halepense (Nackley et al. 2013), have the potential to be used as a feedstock in bioenergy production. Comparisons of 'PowerCane' to specific taxa, $S$. halepense for example, across an invasive spectrum, provided meaningful information. However, making all pairwise comparisons would not be ecologically and statistically meaningful; therefore, our goal was to also find and examine broader trends within invasive groups. Interestingly, our positive control species were selected on the basis of a past history of invasiveness, a robust predictor of future invasiveness (Davis 2009). However, multivariate analysis failed to indicate a relationship between our measured functional traits and our invasive groups (Figure 4). After three growing seasons, our ranking of fitness metrics also fails to show the anticipated consistent gradient of positive (high fitness) to negative (low fitness). This suggests that functional traits vary in their relationship to invasiveness (Dredovsky et al. 2012). 
However, meta-analysis reveals that traits such as fitness, size, and growth rate were significantly higher for exotic invasive species when compared with the traits values of non-invasive species (van Kleunen et al. 2010). It is imperative to remember that invasiveness is not a "one size fits all" scenario, which is made evident in our study. Traits vary with life stage and environmental conditions and the importance of any given trait will therefore also vary (Davis 2009; Pyšek and Richardson 2007). While our positive and negative invasive groups may not have clustered as we hypothesized; the use of numerous species and accessions allows us to evaluate the usefulness of traits across an invasive spectrum.

Unfortunately the loss of our Kentucky and Alabama sites limits our ability to generalize across a broader geographic range. The ability to observe relative comparisons across a gradient of species reinforces the fact that it is the important interaction of species and habitat that result in invasive populations (Barney and Whitlow 2008). Our results indicate that several candidate feedstocks have the ability to move from the cultivated field, but it should be noted that we only recorded spread to $<5 \mathrm{~m}$ from the field edge in three years. On average, more than 100 culms $\mathrm{m}^{-2}$ were observed in every measured quadrat in the Lc receiving area of $S$. halepense, naturalized $M$. sinensis, $P$. virgatum and 'PowerCane'. Conversely, only $S$. halepense and naturalized $M$. sinensis maintained high numbers in the Hc receiving area when $P$. virgatum and $M . \times$ giganteus 'PowerCane' showed a dramatic decrease in culm numbers.

\section{Conclusion}

Bioenergy crop movement beyond the cultivated field would not be novel to agronomic crops because feral escapes are known for most row crops (DiTomaso and Healey 2007). Yet due to their economic and social importance, crops are not frequently discussed in the invasion literature. Our experiment covers the first three years of the establishment phase, and unexpected and nonlinear changes may manifest in subsequent stages. Our results suggest that at least short-range movement away from the cultivated field is probable for fertile bioenergy feedstocks. It should be noted that no species in this study were detected outside our trial boundary, which predominately consisted of a mowed perennial border. Further study, across broader geographic locations and continued research will be necessary to further determine acceptable risk and management planning.

The use of 'PowerCane' or other fertile $M . \times$ giganteus germplasm could improve grower adoption but the invasive potential and ecosystem impacts of widespread cultivation still require further evaluation including the determination of climatic limitations of $M . \times$ giganteus and other bioenergy crop seedlings. The ability to contextualize our results suggests that $M . \times$ giganteus 'PowerCane' did not have the highly competitive seedling establishment potential of $S$. halepense. Alternatively, in this growing region sterile cultivars provide a lower risk option, but require additional economic investment. The scrutiny that has been applied to bioenergy crops indicates that we 
have moved beyond the once cavalier approach toward species introduction. These efforts should continue in order to reduce unwanted and unintentional invasive spread. Nascent populations or seedlings may be easily overlooked. However, management at the seedling or early growth stage will likely increase the chances of successful control (Stephens and Sutherland 1999). Our relative methodology and results from this study can help us prepare for industry development while helping to minimize risk and mitigate invasive spread.

\section{Acknowledgments}

Thanks to Ryan Dougherty, Eugene Dollete, John Halcomb, Matt Ho, Daniel Tekiela, Elise Benhase, Phillip Cox, and Carissa Ervine for help during installation, data collection, and harvest of this experiment. Thanks to Mendel Biotechnology, Inc for donation of M. $\times$ giganteus 'PowerCane' and 'Nagara' plugs and Dr. Erik Sacks for naturalized M. sinensis seed. The USDA graciously provided the two Saccharum spp.

\section{References}

Baker HG (1965) Characteristics and modes of origin of weeds. In: Baker HG, Stebbins GL (Eds) The genetics of colonizing species. Academic Press, New York, New York, USA, 147-169.

Baker HG (1974) The evolution of weeds. Annual Review of Ecology and Systematics 5: 1-24. doi: 10.1146/annurev.es.05.110174.000245

Barney JN, DiTomaso JM (2008) Nonnative species and bioenergy: Are we cultivating the next invader? BioScience 58: 64-70. doi: 10.1641/B580111

Barney JN, DiTomaso JM (2010) Invasive Species Biology, Ecology, Management and Risk Assessment: Evaluating and Mitigating the Invasion Risk of Biofuel Crops. In: Mascia PN, Scheffran J, Widholm JM (Eds) Plant Biotechnology for Sustainable Production of Energy and Co-products. Springer-Verlag, Berlin Heidelberg, 263-284. doi: 10.1007/978-3-64213440-1_9

Barney JN, DiTomaso JM (2011) Global climate niche estimates for bioenergy crops and invasive species of agronomic origin: potential problems and opportunities. PLoS ONE 6: e17222. doi: 10.1371/journal.pone.0017222

Barney JN, Mann JJ, Kyser GB, DiTomaso JM (2012) Assessing habitat susceptibility and resistance to invasion by the bioenergy crops switchgrass and Miscanthus $\times$ giganteus in California. Biomass and Bioenergy 40: 143-154. doi: 10.1016/j.biombioe.2012.02.013

Barney JN, Whitlow TH (2008) A unifying framework for biological invasions: the state factor model. Biological Invasions 10: 259-272. doi: 10.1007/s10530-007-9127-8

Barney JN, Whitlow TH, Lembo AJ (2008) Revealing historic invasion patterns and potential invasion sites for two non-native plant species. PLoS ONE 3: e1635. doi: 10.1371/journal. pone. 0001635 
Beckman JJ, Moser LE, Kubik K, Waller SS (1993) Big bluestem and switchgrass establishment as influenced by seed priming. Agronomy Journal 85: 199-202. doi: 10.2134/agron j1993.00021962008500020007x

Bell GP (1997) Ecology and management of Arundo donax, and approaches to riparian habitat restoration in Southern California. In: Brock JH, Wade M, Pysek P, Green D (Eds) Plant invasions: studies from North America and Europe. Blackhuys Publishers, Leiden, The Netherlands, 103-113.

Blackburn TM, Cassey P, Lockwood JL (2009) The role of species traits in overcoming the small initial population sizes of exotic birds. Global Change Biology 15: 2852-2860. doi: $10.1111 /$ j.1365-2486.2008.01841.x

Boland JM (2006) The importance of layering in the rapid spread of Arundo donax (giant reed). Madrono 53: 303-312. doi: 10.3120/0024-9637(2006)53[303:TIOLIT]2.0.CO;2

Bonin CL, Heaton EA, Barb J (2014) Miscanthus sacchariflorus - biofuel parent or new weed? GCB Bioenergy. doi: 10.1111/gcbb.12098

Connecticut invasive plant list. http://www.cipwg.uconn.edu/pdfs/CTInvasivePlantList2013ScientificName.pdf [accessed 24 March.2014]

Davis AS, Cousens RD, Hill J, Mack RN, Simberloff D, Raghu S (2010) Screening bioenergy feedstock crops to mitigate invasion risk. Frontiers in Ecology and the Environment 8: 533-539. doi: 10.1890/090030

Davis MA (2003) Biotic globalization: does competition from introduced species threaten biodiversity? BioScience 53: 481-489. doi: 10.1641/0006-3568(2003)053[0481:BGDCFI]2.0.CO;2

Davis MA (2009) Biological invasions. Oxford University Press, New York, New York, USA, 244 pp. doi: 10.1016/j.biocon.2009.01.013

Dawson W, Burslem DFRP, Hulme PE (2009) The suitability of weed risk assessment as a conservation tool to identify invasive plant threats in East African rainforests. Biological Conservation 142: 1018-1024.

DiTomaso JM, Healey EA (2007) Weeds of California and Other Western States. University of California Agriculture and Natural Resources, Oakland, CA.

Dougherty RF, Quinn LD, Endres AB, Voigt TB, Barney JN (2014) Natural History Survey of the Ornamental Grass Miscanthus sinensis in the Introduced Range. Invasive Plant Science and Management 7: 113-120. doi: 10.1614/IPSM-D-13-00037.1

Dredovsky RE, Grewell BJ, D’Antonio CM, Funk JL, James JJ, Molinari N, Parker IM, Richards CL (2012) A functional trait perspective on plant invasions. Annals of Botany 110: 141-153. doi: $10.1093 / \mathrm{aob} / \mathrm{mcs} 100$

Gleason HA (1952) New Britton and Brown Illustrated Flora of the Northeastern United States and Adjacent Canada. Lancaster, Lancaster, PA.

Głowacka K, Clark LV, Adhikari S, Peng J, Stewart JR, Nishiwaki A, Yamada T, Jørgensen U, Hidkinson TR, Gifford J, Juvik JA, Sacks EJ (2014) Genetic variation in Miscanthus $\times$ giganteus and the importance of estimating genetic distance thresholds for differentiating clones. Global Change Biology Bioenergy. doi: 10.1111/gcbb.12166

Gordon DR, Onderdonk DA, Fox AM, Stocker RK, Grantz C (2008) Predicting invasive plants in Florida using the Australian weed risk assessment. Invasive Plant Science and Management 1: 178-195. doi: 10.1614/IPSM-07-037.1 
Gordon DR, Tancig KJ, Onderdonk DA, Gantz CA (2011) Assessing the invasive potential of biofuel species proposed for Florida and the United States using the Australian Weed Risk Assessment. Biomass and Bioenergy 35: 74-79. doi: 10.1016/j.biombioe.2010.08.029

Gressel J (2008) Transgenics are imperative for biofuel crops. Plant Science 174: 246-263. doi: 10.1016/j.plantsci.2007.11.009

Heaton E, Clifton-Brown JC, Voigt T, Jones MB, Long SP (2004) Miscanthus for renewable energy generation: European Union experience and projections for Illinios. Mitigation and Adaptation Strategies for Global Change 9: 433-451. doi: 10.1023/B:MITI.00 00038848.94134.be

Hirayoshi I, Nishikawa K, Kato R (1955) Cytogenetical studies on forage plants: Self-incompatability in Miscanthus. Japanese Journal of Plant Breeding 5: 19-22.

Holm LG, Plucknett DL, Juan PV, Herberger JP (1977) The worlds worst weeds. Distribution and biology. University Press of Hawaii, Honolulu, Hawaii, USA, 609 pp.

International Code of Nomenclature for algae, fungi, and plants (Melbourne Code). http://www. iapt-taxon.org/nomen/main.php?page=h.4\&emph=nothospecific [accessed 2014.20 April]

Katibah EF (1984) A brief history of riparian forests in the Central Valley of California. In: Warner RE, Hendrix KE (Eds) Environemntal restoration; science and ecology, conservation, and productive management. Univsersity of California Press, Berkley, California, USA, 22-29.

Kenkel NC, Derksen DA, Thomas AG, Watson PR (2002) Multivariate analysis in weed science research. Weed Science 50: 281-292. doi: 10.1614/0043-1745(2002)050[0281:RM AIWS]2.0.CO;2

Kercher SM, Herr-Turoff A, Zedler JB (2007) Understanding invasion as a process: the case of Phalaris arundinacea in wet praries. Biological Invasions 9: 657-665. doi: 10.1007/ s10530-006-9066-9

Kolar CS, Lodge DM (2001) Progress in invasion biology: predicting invaders. Trends in Ecology and Evolution 16: 199-204. doi: 10.1016/S0169-5347(01)02101-2

Koop AL, Fowler L, Newton LP, Caton BP (2011) Development of a weed screening tool for the United States. Biological Invasions 14: 273-294. doi: 10.1007/s10530-011-0061-4

LaBorde CM (2007) Sugarcane tasseling under artificial photoperiod conditions as affected by nitrogen rate and temperature. Louisiana State University, Baton Rouge, LA.

Lewandowski I, Scurlock JMO, Lindvall E, Christou M (2003) The development and current status of perennial rhizomatous grasses as energy crops in the US and Europe. Biomass and Bioenergy 25: 335-361. doi: 10.1016/S0961-9534(03)00030-8

Lockwood JL, Cassey P, Blackburn T (2005) The role of propagule pressure in explaining species invasions. Trends in Ecology and Evolution 20: 223-228. doi: 10.1016/j. tree.2005.02.004

Lockwood JL, Cassey P, Blackburn TM (2009) The more you introduce the more you get: the role of colonization pressure and propagule pressure in invasion ecology. Diversity and Distributions 15: 904-910. doi: 10.1111/j.1472-4642.2009.00594.x

Madeja G, Umek L, Havens K (2012) Differences in seed set and fill of cultivars of Miscanthus grown in USDA cold hardiness zone 5 and thier potential for invasiveness. Journal of Environmental Horticulture 30: 42-50. 
Mariani C, Cabrini R, Danin A, Piffanelli P, Fricano A, Gomarasca S, Dicandilo M, Grassi F, Soave C (2010) Origin, diffusion and reproduction of the giant reed (Arundo donax L.): a promising weedy energy crop. Annals of Applied Biology 157: 191-202. doi: 10.1111/j.17447348.2010.00419.x

Martin JH, Richard PW, David LS (2006) Principles of Field Crop Production. Prentice Hall, Upper Saddle River, New Jersey, USA.

Martinez-Reyna JM, Vogel KP (2002) Incompatability systems in switchgrass. Crop Science 42: 1800-1805. doi: 10.2135/cropsci2002.1800

Massachusetts prohibited plant list. http://www.mass.gov/eea/agencies/agr/farm-products/ plants/massachusetts-prohibited-plant-list.html [accessed 24 March.2014]

Matlaga DP, Davis AS (2013) Minimizing invasive potential of Miscanthus $\times$ giganteus grown for bioenergy: identifying demographic thresholds for population growth and spread. Journal of Applied Ecology 50: 479-487. doi: 10.1111/1365-2664.12057

Matlaga DP, Quinn LD, Davis AS, Stewart JR (2012a) Light response of native and introduced Miscanthus sinensis seedlings. Invasive Plant Science and Management 5: 363-374. doi: 10.1614/ipsm-d-11-00056.1

Matlaga DP, Schutte BJ, Davis AS (2012b) Age-dependent demographic rates of the bioenergy crop Miscanthus $\times$ giganteus in Illinois. Invasive Plant Science and Management 5: 238-248. doi: 10.1614/IPSM-D-11-00083.1

Meyer MH, Tchida CL (1999) Miscanthus Andress. produces viable seed in four USDA hardiness zones. Journal of Environmental Horticulture 17: 137-140.

Miller JH (2003) Nonnative invasive plants of southern forests: a field guide for identification and control. In: U.S. Department of Agriculture Forest Service SRS (Ed.) Asheville, NC, $93 \mathrm{pp}$.

Nackley LL, Lieu VH, Garcia BB, Richardson JJ, Isaac E, Spies K, Rigdon S, Schwartz DT (2013) Bioenergy that supports ecological restoration. Frontiers in Ecology and the Environment. doi: 10.1890/120241

Parrish DJ, Fike JH (2005) The biology and agronomy of swithchgrass for biofuels. Critical Reviews in Plant Sciences 24: 423-459. doi: 10.1080/07352680500316433

Perrins J, Fitter A, Williamson M (1993) Population biology and rates of invasion of three introduced Impatiens species in the British Isles. Journal of Biogeography 20: 33-44. doi: $10.2307 / 2845737$

US Forest Service, Pacific Island Ecosystems at Risk (PIER). http://www.hear.org/pier/ [accessed 25 August.2014]

Pyšek P, Richardson DM (2007) Traits associated with invasiveness in alien plants: where do we stand? In: Nentwig W (Ed.) Biological Invasions, Ecological Studies 193. SpringerVerlag, Berlin, 97-126. doi: 10.1007/978-3-540-36920-2_7

Quinn LD, Holt JS (2008) Ecological correlates of invasion by Arundo donax in three southern California riparian habitats. Biological Invasions 10: 591-601. doi: 10.1007/s10530-0079155-4

Quinn LD, Matlaga DP, Stewart JR, Davis AS (2011) Empirical Evidence of Long-Distance Dispersal in Miscanthus sinensis and Miscanthus $\times$ giganteus. Invasive Plant Science and Management 4: 142-150. doi: 10.1614/ipsm-d-10-00067.1 
Raghu S, Anderson RC, Daehler CC, Davis AS, Wiedenmann RN, Simberloff D, Mack RN (2006) Ecology. Adding biofuels to the invasive species fire? Science 313: 1742. doi: $10.1126 /$ science. 1129313

Richardson DM, Blanchard R (2011) Learning from our mistakes: Minimizing problems with invasive biofuel plants. Current Opinions in Environmental Sustainability 3: 36-42. doi: 10.1016/j.cosust.2010.11.006

Sacks EJ, Jakob K, Gutterson NI (2013) High biomass Miscanthus varieties. In: Publication USPPA (Ed.), 24 pp.

Saltonstall K, Lambert A, Meyerson LA (2010) Genetics and reproduction of common (Phragmites australis) and giant reed (Arundo donax). Invasive Plant Science and Management 3: 495-505. doi: 10.1614/IPSM-09-053.1

Seawright EK, Rister ME, Lacewell RD, McCorkle DA, Sturdivant AW, Yang C, Goolsby JA (2009) Economic implications for the biological control of Arundo donax: Rio Grande Basin. Southwestern Entomologist 34: 377-394. doi: 10.3958/059.034.0403

Simberloff D, Souza L, Nuñez MA, Barrios-Garcia MN, Bunn W (2012) The natives are restless, but not often and mostly when disturbed. Ecology 3: 598-607. doi: 10.1890/11-1232.1

Smart AJ, Moser LE, Vogel KP (2003) Establishment and seedling growth of big bluestem and switchgrass populations divergently selected for seedling tiller number. Crop Science 43: 1434-1440. doi: 10.2135/cropsci2003.1434

Smith LL (2014) The Thin Green Line: A Framework for Evaluating the Invasive Potential of Bioenergy Crops. Virginia Tech, Blacksburg, VA.

Smith LL, Barney JN (2014a) Contribution of weed management to bioenergy crop yield. In: Gover AE (Ed.) 68th Annual Meeting of the Northeastern Weed Science Society. Philadelphia, PA, 196 pp.

Smith LL, Barney JN (2014b) The relative risk of invasion: Evaluation of Miscanthus $\times$ giganteus seed establishment. Invasive Plant Science and Management 7: 93-106. doi: 10.1614/ IPSM-D-13-00051.1

Stephens PA, Sutherland WJ (1999) Consequences of the Allee effect for behaviour, ecology, and conservation. Trends in Ecology and Evolution 14: 401-405. doi: 10.1016/S01695347(99)01684-5

Thompson K, Davis MA (2011) Why research on traits of invasive plants tells us very little. Trends in Ecology and Evolution 26.

van Kleunen M, Weber E, Fischer M (2010) A meta-analysis of trait differences between invasive and non-invasive platn species. Ecology Letters 13: 235-245. doi: 10.1111/j.14610248.2009.01418.x

Von Holle B (2005) Biotic resistance to invader establishment of a southern Appalachian plant community is determined by environmental conditions. Journal of Ecology 93: 16-26. doi: $10.1111 /$ j.0022-0477.2004.00946.x

Von Holle B, Simberloff D (2005) Ecological resistance to biological invasion overwhelmed by propagule pressure. Ecology 86: 3212-3218. doi: 10.1890/05-0427

Warwick SI, Black LD (1983) The biology of Canadian weeds. 61. Sorghum halepense (L.) PERS. Canadian Journal of Plant Science 63: 997-1014. doi: 10.4141/cjps83-125 
Warwick SI, Thompson LD, Black LD (1984) Population variation in Sorghum halepense, Johnson grass, at the northern limits of its range. Canadian Journal of Botany 62: 1781-1790. doi: 10.1139/b84-242

Web soil survey. http://websoilsurvey.sc.egov.usda.gov [accessed 20 April 2013]

Wilson SB, Knox GW (2006) Landscape performance, flowering, and seed viability of 15 Japanese silver grass cultivars grown in northern and southern Florida. HortTechnology 16: 686-693.

Yauan SJ, Tiller KH, Al-Ahmad H, Stewart NR, Stewart CN (2008) Plants to power: bioenergy to fuel the future. Trends in Plant Science 13: 421-429. doi: 10.1016/j.tplants.2008.06.001 